\title{
Insight on the larval habitat of Afrotropical Culicoides Latreille (Diptera: Ceratopogonidae) in the Niayes area of Senegal, West Africa
}

Mame T. Bakhoum ${ }^{1,2^{*}}$, Assane G. Fall ${ }^{2}$, Moussa Fall², Chiavaroli K. Bassene ${ }^{2}$, Thierry Baldet ${ }^{1}$, Momar T. Seck $^{2}$, Jérémy Bouyer ${ }^{1,3}$, Claire Garros $^{1+}$ and Geoffrey Gimonneau ${ }^{1,2,4,5+}$

\begin{abstract}
Background: Certain biting midges species of the genus Culicoides (Diptera: Ceratopogonidae) are vectors of virus to livestock worldwide. Culicoides larval ecology has remained overlooked because of difficulties to identify breeding sites, methodological constraints to collect samples and lack of morphological tools to identify fieldcollected individuals to the species level. After the 2007 unforeseen outbreaks of African horse sickness virus (AHSV) in Senegal (West Africa), there is a need to identify suitable and productive larval habitats in horse farms for the main Culicoides species to evaluate the implementation of vector control measures or preventive actions.

Methods: We investigate twelve putative larval habitats (habitat types) of Culicoides inside and outside of three horse farms in the Niayes area of Senegal using a combination of flotation and emergence methods during four collection sessions.

Results: Among the three studied horse farms, three habitat types were found positive for Culicoides larvae: pond edge, lake edge and puddle edge. A total of 1420 Culicoides individuals ( $519 \sigma^{\lambda} / 901$ ) belonging to ten species emerged from the substrate samples. Culicoides oxystoma (40 \%), C. similis (25\%) and C. nivosus (24\%) were the most abundant species and emerged from the three habitat types while C. kingi (5\%) was only retrieved from lake edges and one male emerged from puddle edge. Culicoides imicola (1.7 \%) was found in low numbers and retrieved only from pond and puddle edges.

Conclusions: Larval habitats identified were not species-specific. All positive larval habitats were found outside the horse farms. This study provides original baseline information on larval habitats of Culicoides species in Senegal in an area endemic for AHSV, in particular for species of interest in animal health. These data will serve as a point of reference for future investigations on larval ecology and larval control measures.
\end{abstract}

Keywords: Culicoides, Larval habitats, Flotation technique, Senegal, African horse sickness

Abbreviations: BTV, Bluetongue virus; AHSV, African horse sickness virus; AHS, African horse sickness

\footnotetext{
* Correspondence: thierno.bakhoum@cirad.fr

${ }^{\dagger}$ Equal contributors

${ }^{1}$ Cirad, UMR CMAEE, Montpellier, France

${ }^{2}$ Institut Sénégalais de Recherches Agricoles, Laboratoire National de

I'Elevage et de Recherches Vétérinaires, BP 2057, Dakar-Hann, Sénégal

Full list of author information is available at the end of the article
} 


\section{Background}

Biting midge species of the genus Culicoides Latreille (Diptera: Ceratopogonidae) comprise around 1358 described species distributed worldwide [1]. Certain Culicoides species are known as the biological or putative vectors of viruses of domestic and wild ruminants as well as horses, such as the Schmallenberg virus (SBV), Akabane virus (AKAV), Bluetongue (BT) virus, epizootic haemorrhagic disease (EHD) virus and African horse sickness (AHS) virus [2,3]. Vector control strategies for Culicoides spp. are needed. Indeed, vector control aims at reducing density of Culicoides populations at adult and larval stages, to limit host-vector contacts and hence decrease virus transmission $[4,5]$. Among putative strategies, biological, chemical or environmental control of immature stages have been overlooked principally because oviposition behavior, breeding sites, larval habitats and factors regulating immature abundance are mostly unknown for Culicoides vector species. Baseline data on larval habitats of main vector species worldwide are needed to have a better understanding of their ecology and to provide new insights to the development of efficient vector control measures [6-9].

Culicoides spp. larval habitats are usually defined as humid rich and enriched in animal or vegetal organic matter, and may cover a wide range of natural and artificial substrates. Indeed, many larval habitats are described worldwide, including freshwater marshes and swamps, shallow margins of ponds, streams and rivers, bogs and peat lands, beaches, around leaking irrigation pipes and water troughs, tree holes and other natural cavities in rotting wood, waterlogged pastures, animal manure, rotting fallen fruits, highly alkaline or saline inland pools and animal dung [10-20].

Species diversity of Culicoides could be locally high [21-23], but it is admitted that only a limited number of species are able to transmit AHSV or BTV [2]. Consequently, larval ecology of only abundant vector species is described for livestock-related areas in some areas where the species occur $[13,23-25]$. The main BTV vector in northern America, C. sonorensisis associated with edges of wastewater and polluted ponds on farms, but other aquatic sources (irrigation runoff in pasture, puddles, trough spillover) have also been found as high productive habitats $[4,23,26]$. In the Oriental and Australasian regions, $C$. brevitarsis larvae are mainly found associated with cattle dung $[27,28]$ unlike those of $C$. oxystoma which are found in aquatic and semi-aquatic habitats, such as paddy fields, stream edges, pond margins or estuary [28-30]. Larvae of the BTV vector species belonging to the subgenus Avaritia in the Palaearctic region (C. obsoletus, C. scoticus, C. dewulfi, C. chiopterus and C. dewulfi) are usually mentioned in the literature associated with cattle dung or cattle/sheep farm environment
[13, 25, 31, 32], whereas C. obsoletus and C. scoticus could occupy a wide range of habitats inside and outside farm buildings [13, 32]. Culicoides chiopterus and $C$. dewulfi showed preferences for high soil moisture [33] and are referred as cattle dung breeders [34].

Certain species, e.g. C. imicola, have a wide range of larval habitats. Initially, larvae of C. imicola (affiliated to the subgenus Avaritia) are reported in permanent moist grassed margins of streams, furrows where grass is kept short by grazing animals in its southern historical distribution range (i.e. in South Africa) [17]. In northern Sardinia, an island in the Mediterranean, larval habitats of $C$. imicola are muddy habitats, not waterlogged, above unvegetated pond margins [24], which matches the first observations of C. imicola larval habitats in South Africa [18]. In Israel, Braverman et al. [11] described abundant larval populations in rich mixture of organic matter and water saturated soil, and concluded that this substrate was the favorable habitat of $C$. imicola (named by its synonym name C. pallidipennis in the article). Other descriptions of C. imicola larval habitats are detailed from Kenya [15], Nigeria [12] and Rhodesia (equivalent in territorial terms to modern Zimbabwe) [35], but suspected taxonomic uncertainty or misidentification [17] made the larval habitat descriptions doubtful for C. imicola. The anecdotal record of C. imicola by Nevill [36] breeding in cattle dung is also considered by Meiswinkel a misidentification [17]. Therefore, in the Afrotropical region, favorable larval habitats of C. imicola, the main vector species of AHSV and BTV, are only well described from South Africa. Apart from C. imicola, larval habitats of other Afrotropical species were investigated mostly in South Africa $[14,16,18,19]$, Zimbabwe [35] Nigeria [12] and Kenya [15]. These larval habitats can be grouped into four main types: (i) moist soil enriched greater or lesser in organic matter (decomposing plant matter, varying from intact material to humus, or of decomposed dung, such as is often found on irrigated pastures) with a great diversity of associated species $[12,15,16,18]$; (ii) tree holes and other natural cavities in rotting wood, with often rare species such as C. accraensis, C. inornatipennis, C. clarkei, C. confusus, C. eriodendroni, C. nigripennis, C. olyslageri and $C$. punctithorax $[16,18]$; (iii) dung pats of large herbivores such as African buffalo and cattle; and (iv) rotting fallen fruits of the sausage tree. The latter two larval habitat types are used respectively by $C$. bolitinos $[16,17]$ and C. tuttifrutti [16]. Overall, for the Afrotropical region, data on Culicoides larval habitats are scarce and mostly limited to southern Africa. Moreover, most of the studies have described favorable larval habitats in bovine environment areas [15-17, 35]. Despite the importance of AHSV in the African region, no larval habitats of Culicoides spp. are described in horse-surrounding ecosystems and no species are associated with horse dung. 
Immature stages are localized at the substrate surface [37, 38]. Different techniques were used to investigate Culicoides spp. larval habitats and to determine the presence/absence and abundance of Culicoides larvae: sampling larvae from the substrate, emergence traps in the field and emergence pots. Larval collection methodology has been described and reviewed in [39] and sugar flotation provides the most effective results with low larval mortality [34]. Emergence methods are practiced by installing emergence traps directly in the field or by incubating the substrate samples in controlled environment with optimal conditions $[12,14,15]$. For larval ecology studies, a combination of both methods is necessary because no identification keys for immature stages exist for Culicoides spp. Recently, molecular identification of Culicoides larvae has been used through barcode sequences $[28,40]$. This approach is powerful but is only applicable if the species diversity in a specific area has already been barcoded.

In Senegal, 53 species of Culicoides are recorded including species proven or suspected biological vectors of viruses of interest in animal health such as C. imicola, $C$. bolitinos, C. kingi and C. oxystoma [21, 22, 41, 42]. The country faced outbreaks of African horse sickness (AHS) in 2007 which caused the death of 1169 horses and considerable economic losses, estimated to 1.4 million euros $[43,44]$.

This study was designed to provide baseline information on larval habitats of Afrotropical Culicoides spp., in particular for species proven or suspected biological vectors of viruses in three horse farms in a known AHS-endemic region in Senegal. Identifying larval habitats in this area may serve as a point of reference for future investigations on larval ecology and larval control measures as already investigated in some regions $[5,7,45]$.

\section{Methods}

\section{Study sites}

The study was conducted in three horse farms affected by the 2007 AHS epizootic in the Niayes area in the vicinity of Dakar and Thiès, Senegal (Fig. 1) (see references [21, 42] for study region description): (a) Horse farm of Mbao (latitude: 14.7467, longitude: -17.3327) is a riding centre with 32 horses surrounded by a protected forested area. (b) Horse farm of Niague (latitude:14.8234, longitude: -17.2499) is a riding centre with 30 horses, 1 donkey and less than 10 cows or sheep, surrounded by a market-gardening area. (c) Horse farm of Pout (latitude: 14.7665, longitude: -17.0357) is a modern farm located

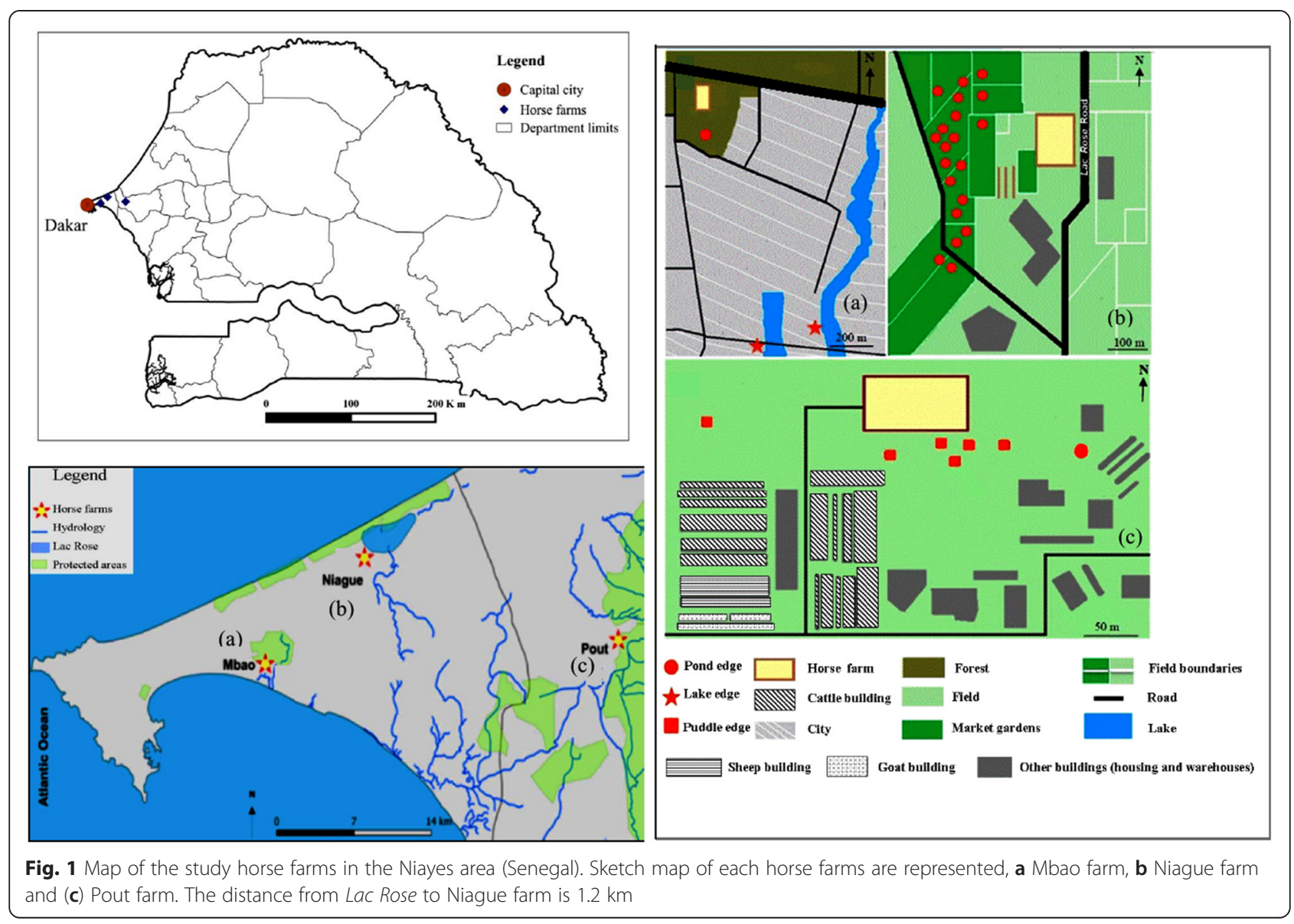


in a rural environment. The latter site owns a wide range of animals in high numbers: 20 equids, 1700 sheep, 240 goats and 1600 cows or buffaloes. In each horse farm, dung and manure in animal buildings and boxes were removed every day and accumulated outside horse farms before being used for field spreading by local farmers. Previous entomological monitoring conducted in the three horse farms revealed high abundance and large diversity of Culicoides spp. [21, 22].

\section{Larval habitat classification, sample collection strategy and monitoring}

We have defined and described twelve putative larval habitats (habitat types) inside and outside horse farms with reference to the literature to match previous classifications
[31] (Figs. 1 and 2). At each horse farm, all the twelve defined putative larval habitat types were investigated at several sampling sites if available (Table 1).

Samples were collected in September-October 2014 during four collection sessions (16th September, 30th September, 15th October and 30th October), corresponding to the end of the rainy season. For each available defined habitat type (Fig. 2, Table 1), one substrate sample of approximately $650 \mathrm{~cm}^{3}$ was collected in the upper layer of soil surface $(0-5 \mathrm{~cm})$ with a trowel, filtered with a fine mesh sieve of $0.8 \mathrm{~mm}$ diameter and then investigated for midge larvae in the field using a direct flotation technique in saturated sugar solution $(850 \mathrm{~g} / \mathrm{l})$. Presence/ absence of midge larvae was used as a proxy for positive larval habitat. If no midge larvae were observed in the first

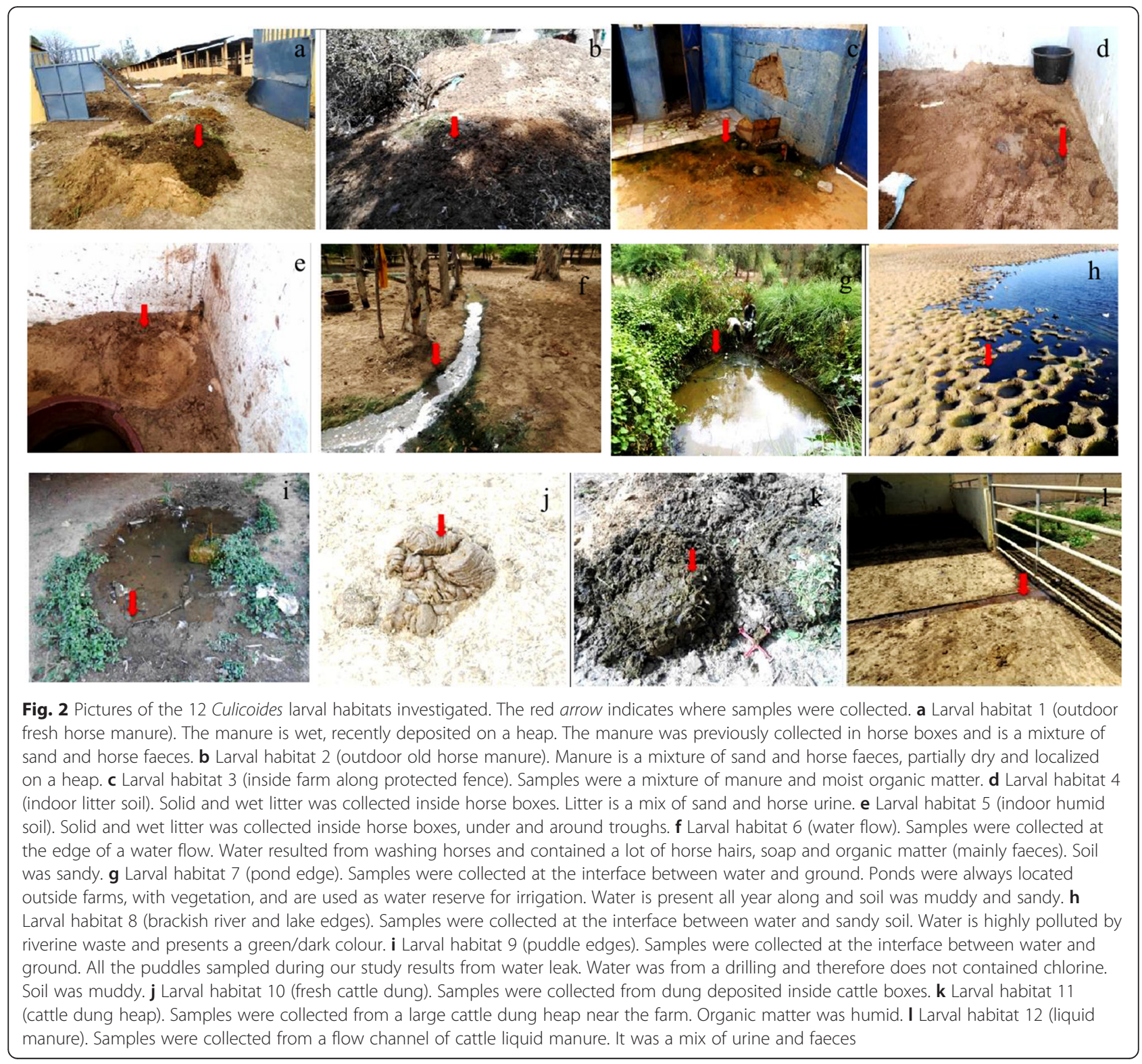


Table 1 Number of flotation for each of the twelve Culicoides larval habitats investigated according to horse farm and collection session

\begin{tabular}{|c|c|c|c|c|c|c|c|c|c|c|c|c|c|}
\hline \multirow[b]{3}{*}{ Larval habitat } & \multicolumn{12}{|c|}{ Number of flotation/Horse farm/Collection session } & \multirow[b]{3}{*}{ Total } \\
\hline & \multicolumn{3}{|c|}{$16^{\text {th }}$ September } & \multicolumn{3}{|c|}{$30^{\text {th }}$ September } & \multicolumn{3}{|c|}{$15^{\text {th }}$ October } & \multicolumn{3}{|c|}{$30^{\text {th }}$ October } & \\
\hline & $\bar{A}$ & $B$ & C & $\bar{A}$ & $\mathrm{~B}$ & C & $\bar{A}$ & $\mathrm{~B}$ & C & $\bar{A}$ & $B$ & C & \\
\hline 1. Outdoor fresh horse manure & 3 & 2 & 3 & 2 & - & - & - & - & - & - & - & - & 10 \\
\hline 2. Outdoor old horse manure & 2 & 5 & - & 2 & - & - & 2 & 2 & - & - & - & - & 13 \\
\hline 3. Inside farm along protected & - & 2 & - & - & - & - & - & - & - & - & - & - & 2 \\
\hline 4. Indoor litter soil & 7 & 5 & 3 & 6 & - & 5 & 2 & - & 4 & - & - & 4 & 36 \\
\hline 5. Indoor humid soil & 6 & 2 & 2 & 4 & - & 2 & - & - & - & - & - & - & 16 \\
\hline 6. Water flow & 2 & - & - & - & - & - & - & - & - & - & - & - & 2 \\
\hline 7. Pond edge & 1 & 6 & - & 1 & - & - & 1 & 9 & - & 1 & 5 & - & 24 \\
\hline 8. Lake edge & - & - & - & 1 & - & - & 2 & - & - & 2 & 1 & - & 6 \\
\hline 9. Puddles edge & 4 & - & 2 & 6 & - & 5 & - & - & 4 & - & - & 3 & 24 \\
\hline 10. Fresh cattle dung & - & 2 & - & - & - & 4 & - & 2 & 4 & - & - & 2 & 14 \\
\hline 11. Cattle dung heap & - & - & - & - & - & 3 & - & - & 2 & - & - & 2 & 7 \\
\hline 12. Liquid manure & - & - & - & - & - & 3 & - & - & 2 & - & - & 2 & 7 \\
\hline Total & 25 & 24 & 10 & 22 & - & 22 & 7 & 13 & 16 & 3 & 6 & 13 & 161 \\
\hline
\end{tabular}

Abbreviations: $A$ horse farm of Mbao, $B$ horse farm of Niague, $C$ horse farm of Pout

flotation sample, a second replicate was collected if possible. For each positive flotation sample, up to three samples of approximately $125 \mathrm{~cm}^{3}$ were collected from the $0-5 \mathrm{~cm}$ of soil using a trowel and placed in $200 \mathrm{ml}$ plastic pots covered with a net before being transported to the laboratory (insectarium) to monitor adult emergence. Emerging pots were maintained for 21 days at a temperature of $25 \pm 1{ }^{\circ} \mathrm{C}$, relative humidity of $80 \pm 10 \%$ and a light:dark photoperiod of 12:12 $\mathrm{h}$ to allow the retrieval of emerging adult Culicoides. The surface of the substrate was sprayed every two days with demineralized water to prevent desiccation. Each day, emerging adults were collected using a mouth-operated aspirator and then preserved in $90^{\circ}$ ethanol. Culicoides species identifications were done on emerged adults using a stereomicroscope (10-40x) and reference identification keys [46-48].

\section{Results}

For the three horse farms and the four collection sessions, a total of 161 flotation samples were collected (Table 1). Of these, 45 samples (28 \%) were positive for Culicoides spp. larvae, which resulted in 135 emergence pots.

Among the 12 putative larval habitats, three larval habitats were found positive for Culicoides larvae using sugar flotation collection method: (g) pond edge, (h) lake edge and (i) puddle edges (Fig. 2). No larvae were retrieved of samples from putative larval habitats associated with horse faeces; from a mixture of organic matter and water and from putative larval habitats associated with cattle dung (Fig. 2). All of the positive sampling sites for these three larval habitats were localized outside horse farms (Fig. 1).

A total of 1420 adult Culicoides (519 $\delta / 901$ क) belonging to 10 species emerged from the 135 substrate samples in the laboratory (Tables 2 and 3; Figs. 3, 4 and 5) together with other dipteran species belonging to the families Ceratopogonidae (genus Forcipomyia) and Psychodidae (data not shown).

For the three positive larval habitats, $90 \%$ of the emerged specimens belong to three species: C. oxystoma $(n=568), C$. similis $(n=362)$ and C. nivosus $(n=341)$ (Table 2). Less than $2 \%$ of the emerged Culicoides were identified as C. imicola (25 individuals) in horse farms of Niague and Pout from pond edge and puddle edge, respectively (Tables 2 and 3). Culicoides kingi emerged almost exclusively in horse farms of Mbao and Niague from lake edge; only a single individual emerged from puddle edge in horse farm of Pout. The density of emerged species varied according to larval habitats (Figs. 3 and 4).

The overall sex ratio was unbalanced towards females $(\mathrm{SR}=0.58)$, which was also observed for the two most abundant species (C. oxystoma and C. similis) and all of the positive larval habitats (Table 3 ). At horse farms of Mbao and Niague, the most productive larval habitats were pond edges ( 88 and $83 \%$ of the emerging adults, respectively) (Fig. 3, Table 2). At horse farm of Pout, $99 \%$ of the emerging adults (both sexes) were obtained from puddle edge (Table 2$)$. The highest number $(n=644)$ of emerging individuals was found at horse farm of Mbao, followed by horse farm of Pout $(n=469)$ and horse farm of Niague $(n=307)$ (Table 3$)$. The study of emergence 
Table 2 Mean (minimum-maximum) number of Culicoides individuals emerged from substrate samples per species, site and larval habitat type

\begin{tabular}{|c|c|c|c|c|c|c|c|c|c|c|}
\hline \multirow[t]{2}{*}{ Species/Site } & \multicolumn{3}{|l|}{ Pond edge } & \multicolumn{3}{|l|}{ Lake edge } & \multicolumn{3}{|c|}{ Puddle edge } & \multirow[t]{2}{*}{ Total numbe } \\
\hline & $A^{a}$ & $B^{b}$ & $\mathrm{C}^{\mathrm{a}}$ & $A^{c}$ & $B^{a}$ & C & A & B & $C^{d}$ & \\
\hline C. oxystoma & $49.8(26-75)$ & $26.3(3-78)$ & 1.3 & $10.8(5-23)$ & 1.3 & - & - & - & $56.5(16-160)$ & 568 \\
\hline C. similis & 48.5 (6-99) & $29.5(3-54)$ & - & - & 1.3 & - & - & - & $11.3(9-20)$ & 362 \\
\hline C. nivosus & $37.8(11-65)$ & 1.5 & - & $1.5(1-5)$ & 3.5 & - & - & - & $41(3-108)$ & 341 \\
\hline C. kingi & - & - & - & $10.3(3-38)$ & 6.3 & - & - & - & 0.3 & 67 \\
\hline C. enderleini & $6.5(1-22)$ & $2.3(1-8)$ & - & 0.5 & 0.5 & - & - & - & $2.3(1-8)$ & 45 \\
\hline C. imicola & - & $3(1-7)$ & - & - & - & - & - & - & $3.3(2-5)$ & 25 \\
\hline C. pycnostictus & - & - & - & - & - & - & - & - & 1.3 & 5 \\
\hline C. moreli & - & 1 & - & - & - & - & - & - & - & 4 \\
\hline C. leucosticus & - & 0.3 & - & - & - & - & - & - & 0.3 & 2 \\
\hline C. expectator & - & 0.3 & - & - & - & - & - & - & - & 1 \\
\hline
\end{tabular}

Abbreviations: $A$ horse farm of Mbao; $B$ horse farm of Niague, $C$ horse farm of Pout

a One sampling site sampled

${ }^{\mathrm{b}}$ Four to six sampling sites sampled

'One to two sampling sites sampled

${ }^{d}$ Four to five sampling sites sampled

dynamics showed marked variations between sites, larval habitats and species (Fig. 5), probably due to the different environmental and meteorological conditions.

\section{Discussion}

Larval habitats of Culicoides vector species are investigated in many areas in the world where the species occur. In the Afrotropical region where AHSV is endemic, larval habitats of Culicoides are almost unknown or require an update except for the southern part of the continent where Culicoides larval habitats are much investigated $[14,16,19]$.

To our knowledge, this study is the first to identify larval habitats of several Culicoides species, including the species potentially involved in AHSV transmission, in the Niayes area, Senegal, West Africa, in horse-related ecosystems. Positive larval habitats were recorded only outside horse farms. No species-specific habitats were identified although $C$. kingi was particularly abundant in lake edge habitats in horse farms of Mbao and Niague; just one individual emerged from puddle edge in horse farm of Pout. Since the last outbreak of AHSV in 2007 in Senegal, several studies have been conducted in the same horse farms in the Niayes area to characterize Culicoides species diversity [21, 41, 42], trophic behaviour $[42,49-51]$ and population dynamics $[21,22]$ at the adult stage. These surveys conducted on adult populations in these three horse farms using suction black-light traps

Table 3 Sex ratio (SR) of Culicoides individuals emerged from substrate samples per species, horse farm and larval habitat type

\begin{tabular}{|c|c|c|c|c|c|c|c|c|c|c|}
\hline \multirow[b]{2}{*}{ Species/Sites } & \multicolumn{3}{|l|}{ Pond edge } & \multicolumn{3}{|l|}{ Lake edge } & \multicolumn{3}{|c|}{ Puddle edge } & \multirow[b]{2}{*}{ Total } \\
\hline & A & $B$ & $C$ & A & B & C & A & $B$ & $C$ & \\
\hline C. oxystoma & $63 \delta^{\pi} / 136$ 우 & $38 \hat{\delta} / 67$ ㅇ & $2 \delta / 3$ ㅇ & $9 \delta^{\pi} / 19$ q & $5 q$ & - & - & - & $100 \delta^{\pi} / 126$ 우 & $212 \delta^{\pi} / 356$ ㅇ \\
\hline C. similis & $75 \delta^{\pi / 119}+$ & $52 \delta^{\pi} / 66$ 우 & - & - & 5우 & - & - & - & $17 \delta / 28+$ & $144 \delta^{\pi} / 218$ q \\
\hline C. nivosus & 36 ôn $/ 115$ q & $4 \hat{\delta} / 2+$ & - & $1 \delta / 5$ 우 & $5 \delta / 9 q$ & - & - & - & 72 ふ/92 우 & $118 \delta^{\pi} / 223 q$ \\
\hline C. kingi & - & - & - & $21 \delta / 20$ 웅 & $4 \delta^{\pi} / 21$ q & - & - & - & 10 & $26 \sigma^{\pi} / 41+$ \\
\hline C. enderleini & $3 \sigma^{\pi} / 20$ ㅇ & $2 \hat{\delta} / 7$ 우 & - & $2 q$ & $10 / 1$ ㅇ & - & - & - & $2 \pi / 7$ 우 & $83^{\pi} / 37$ ㅇ \\
\hline C. imicola & - & $2 \sigma^{\lambda} / 10 q$ & - & - & - & - & - & - & $4 \pi / 9$ ㅇ & $6 \delta^{\lambda / 19}+$ \\
\hline C. pycnostictus & - & - & - & - & - & - & - & - & $2 \pi / 3$ 웅 & $2 \hat{\delta} / 3$ 우 \\
\hline C. moreli & - & $4+$ & - & - & - & - & - & - & - & 4 우 \\
\hline C. leucosticus & - & $1 \hat{\sigma}$ & - & - & - & - & - & - & $1 \hat{\sigma}$ & 20 \\
\hline C. expectator & - & 10 & - & - & - & - & - & - & - & 10 \\
\hline Total & $177 \delta / 390$ o & $100 \widehat{\delta} / 156$ 우 & $20 / 3$ 우 & $31 \delta / 46$ q & $10 \widehat{\jmath} / 41$ ㅇ & - & - & - & $199 \delta^{\pi / 265}$ ㅇ & $\begin{array}{l}519 \sigma^{\pi} / 901 \text { 우 } \\
(\mathrm{SR}=0.58)\end{array}$ \\
\hline
\end{tabular}




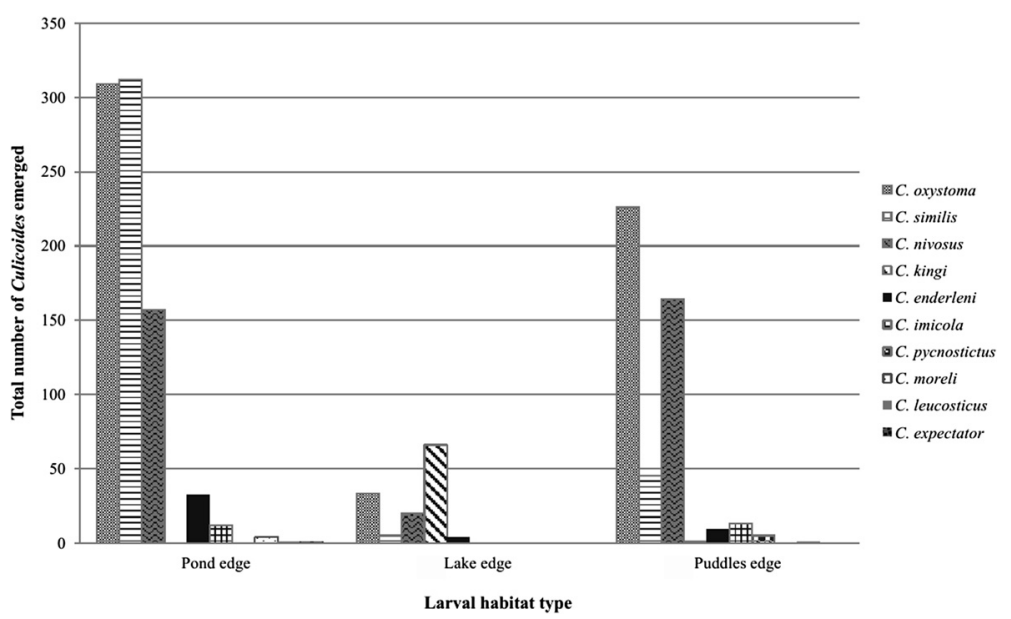

Fig. 3 Number of emerged individuals per species for each larval habitat type

revealed a high species diversity with at least 18 species collected [21, 42], whereas 10 species emerged from the collected substrates in our study. Of these 10 species, eight are proven or suspected biological vectors of viruses of interest in animal health: Culicoides imicola major vector of AHSV in Afrotropical region [52-55], C. oxystoma [56, 57], C. kingi, C. enderleini, C. nivosus, C. leucostictus, C. pycnostictus and C. exspectator [55]. Culicoides kingi is involved in the transmission of Onchocerca gutturosa, a parasite of cattle [58].

It is known that the abundance of Culicoides larvae collected or emerged from substrates is lower than that of Culicoides adults collected using suction black-light traps. Thus, abundance of $C$. sonorensis adults collected in two dairy farms in Northern California using suction black-light traps was weakly correlated with that of the larvae [23]. Auriault et al. [59] followed during three years $C$. grahamii populations at both adult and larval stages in Gabon. These authors did not identify the larval habitats of this species using emergence traps in an environment of debris and decomposing banana trunks while C. grahamii adult populations were abundant and caused a nuisance to humans [59].

Interestingly, only semi-aquatic freshwater and saltwater habitats were positive for Culicoides larvae in our study; these were similar to some described larval habitats in South Africa [14, 18] and Kenya [15]. Other larval habitats mentioned in the Afrotropical literature such as the dung pats of large herbivores $[16,17]$ were found negative for Culicoides larvae in our study. Indeed, no larvae were found in horse and cattle dungs investigated in our study and all larval habitats identified were located outside the horse farms, in the immediate surroundings, and all represented permanent semi-aquatic habitats.

The absence of positive larval habitats inside horse farms may be due to the daily mechanical disturbance of horse litter. This may affect and limit the attraction of gravid females to these putative breeding sites and oviposition site choice. Indeed, mechanical disturbance may affect larval development of biting midges [60]. Moreover, insecticides are regularly sprayed in some horse boxes against arthropod vectors which could affect

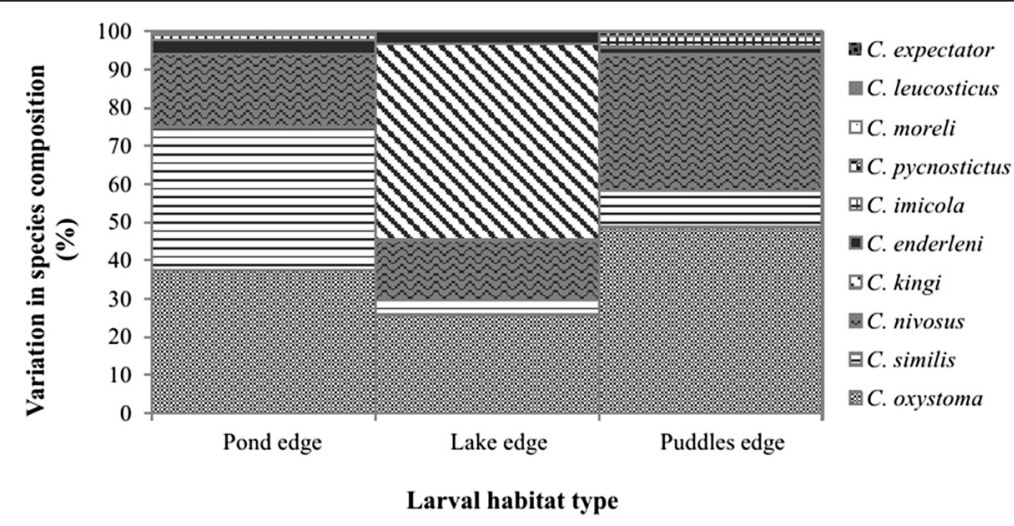

Fig. 4 Species composition for each larval habitat type 

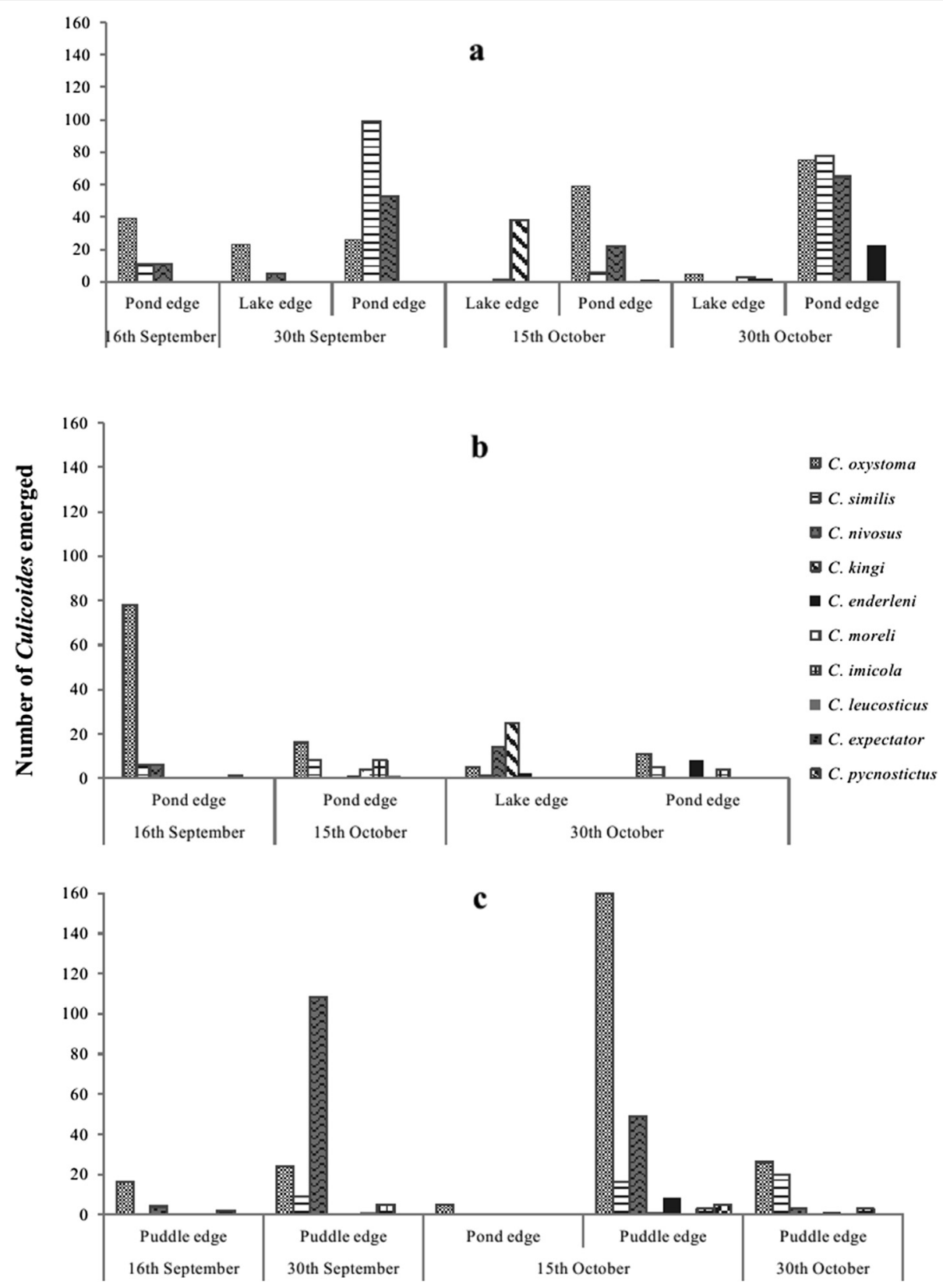

Fig. 5 Emergence dynamics at the positive larval habitats at each horse farm according to collection session. a Mbao farm, b Niague farm and $\mathbf{c}$ Pout farm

adult Culicoides oviposition and survival. Several studies have examined insecticides against Culicoides spp. and depending on the specific product; their efficacy to reduce attack rates and the survival of Culicoides spp. was more or less satisfying [60-62].

In our study, the overall sex ratio was unbalanced towards females, which is also observed for other studies $[14,32]$. The numbers of emerged individuals and the composition of Culicoides spp. varied according to larval habitats and horse farms but also collection sessions (16th September, 30th September, 15th October and 30th October). Culicoides kingi and C. imicola, two important species of veterinary importance, emerged in very low numbers from field-collected substrate samples whereas adult specimens were abundantly collected at the same period in the same sites using suction black-light traps [21,22]. The same was observed for C. imicola in South Africa by $[14,18]$. Different hypothesis could explain these discrepancies. The developmental success and emergence rates might have been impacted in emerging pots in the laboratory. Even though larvae were reared in substrates from their natural habitats, the transfer of samples into the pot, and then from the field to the lab, changes the environmental conditions 
and may have induced mortality. Moreover, favourable larval habitats of $C$. imicola may have been probably poorly sampled or not sampled during the field investigations.

Culicoides kingi and C. oxystoma were the dominant species found around the brackish lake edges in Mbao and Niague. Further analyses of the substrate physicochemical properties may provide a better understanding of specific environmental requirements for these species. Culicoides oxystoma was found in all positive larval habitats (pond edge, lake edge and puddle edge). Larvae of this species were also found in several aquatic and semiaquatic habitats in Japan and India, such as paddy fields, stream edges and pond margins [28-30]. Culicoides oxystoma has a wide range of larval habitats such as the case of C. imicola in several areas where this species is present $[14,16,18,24]$.

\section{Conclusions}

The combination of flotation and emergence methods was used to investigate 12 putative larval habitats; of these, three larval habitats were found outside the horse farms, in the immediate surroundings and represented permanent semi-aquatic habitats. No larvae were retrieved from larval habitat types associated with dung (horse dungs, fresh and heap cattle dungs). Although preliminary, these baseline results are very important to further insights into the larval habitats of Culicoides spp. in the Niayes area, an AHS endemic region in Senegal, before conducting further studies.

\section{Acknowledgements}

The authors are grateful to all the people who gave assistance in operating prospective.

\section{Funding}

MTB was granted by the Islamic Development Bank (Ref. 36/11207330; File No. 66/SEN/P34) and was funded for the field studied by a Cirad grant. This work was funded by the project 'Integrated Vector Management: innovating to improve control and reduce environmental impacts' of Institut Carnot Santé Animale (ICSA) excellence network (http://www6.jouy.inra.fr/gabi/ Le-Partenariat/L-Institut-Carnot-Sante-Animale-ICSA) and also by the EU FP7HEALTH-2010-single-stage grant 261504 EDENext. This paper is catalogued by the EDENext Steering Committee as EDENext 365 (http://www.edenext.eu). The contents of this publication are the sole responsibility of the authors and do not necessarily reflect the views of the European Commission.

\section{Availability of data and materials}

The data supporting the conclusions of this article are included within the article.

\section{Authors' contributions}

AGF and GG designed and supervised the study. MTB, CKB and GG performed the collections sampling and global management of the entomological material. MTB, MF and CKB performed species identification. MTB, AGF, MTS, TB, JB, CG and GG wrote the first draft of the manuscript. All authors revised and approved the final version of the manuscript.

\section{Competing interests}

The authors declare that they have no competing interests.
Ethics approval and consent to participate

Not applicable.

\section{Author details}

${ }^{1}$ Cirad, UMR CMAEE, Montpellier, France. ${ }^{2}$ Institut Sénégalais de Recherches Agricoles, Laboratoire National de l'Elevage et de Recherches Vétérinaires, BP 2057, Dakar-Hann, Sénégal. ${ }^{3}$ PATTEC coordination office, P. O. Box 3243 , Addis Ababa, Ethiopia. ${ }^{4}$ Cirad, UMR INTERTRYP, F-34398, Montpellier, France.

${ }^{5}$ Present address: CIRDES, BP454, Bobo-Dioulasso, Burkina Faso.

Received: 9 March 2016 Accepted: 11 August 2016

Published online: 22 August 2016

\section{References}

1. Borkent A. World species of biting midges (Diptera: Ceratopogonidae). 2016. http://wwx.inhs.illinois.edu/files/5014/6532/8290/ CulicoidesSubgenera.pdf.

2. Mellor PS, Boorman J, Baylis M. Culicoides biting midges: their role as arbovirus vectors. Annu Rev Entomol. 2000;45:307-40.

3. Purse BV, Carpenter S, Venter GJ, Bellis G, Mullens BA. Bionomics of temperate and tropical Culicoides midges: knowledge gaps and consequences for transmission of Culicoides-borne viruses. Annu Rev Entomol. 2015;60:373-92.

4. Mullens B, Duranti A, McDermott EG, Gerry AC. Progress and knowledge gaps in Culicoides ecology and control. Vet Ital. 2015;51(4):313-23.

5. Carpenter S, Mellor PS, Torr SJ. Control techniques for Culicoides biting midges and their application in the U.K. and northwestern Palaearctic. Med Vet Entomol. 2008;22:175-87.

6. Ansari MA, Carpenter S, Butt TM. Susceptibility of Culicoides biting midge larvae to the insect-pathogenic fungus, Metarhizium anisopliae: prospects for bluetongue vector control. Acta Trop. 2010;113(1):1-6.

7. Harrup LE, Gubbins S, Barber J, Denison E, Mellor PS, Purse BV, Carpenter S. Does covering of farm-associated Culicoides larval habitat reduce adult populations in the United Kingdom? Vet Parasitol. 2014;201(1-2):137-45.

8. Nicholas AH, McCorkell B. Evaluation of Metarhizium anisopliae for the control of Culicoides brevitarsis Kieffer (Diptera: Ceratopogonidae), the principal vector of bluetongue virus in Australia. J Vector Ecol. 2014;39(1):2013-8

9. Holbrook FR, Agun SK. Field trials of pesticides to control larval Culicoides variipennis (Ceratopogonidae). Mosq News. 1984;44(2):233-6.

10. Blackwell A, Young MR, Mordue W. The microhabitat of Culicoides impunctatus (Diptera: Ceratopogonidae) larvae in Scotland. Bull Entomol Res. 1994;84:295-301.

11. Braverman Y, Galun RM, Ziv M. Breeding sites of some Culicoides species (Diptera: Ceratopogonidae) in Israël. Mosq News. 1974;34(3):303-8.

12. Dipeolu OO, Ogunrinade AF. Species of Culicoides breeding on rocks and riverbanks in Nigeria. Ecol Entomol. 1976;1:267-74.

13. Gonzalez M, Lopez S, Mullens BA, Baldet T, Goldarazena A. A survey of Culicoides developmental sites on a farm in northern Spain, with a brief review of immature habitats of European species. Vet Parasitol. 2013;191(1-2):81-93

14. Jenkins $A B$, Young MB. Breeding sites of Culicoides midges in KwaZulu-Natal. S Afr J Anim Sci. 2010;40(10):510-3.

15. Lubega R, Khamala PM. Larval habitats of common Culicoides Latreille (Diptera, Ceratopogonidae) in Kenya. Bull Entomol Res. 1976;66:421-5.

16. Meiswinkel R, Venter GJ, Nevill EM. Vectors: Culicoides spp. In: Tustin JAWCaRC, editor. Infectious Diseases of Livestock. Cape Town: Oxford University Press; 2004. p. 93-136.

17. Meiswinkel R. Afrotropical Culicoides: a redescription of C. (Avaritia) imicola kieffer, 1913 (Diptera: Ceratopogonidae) with description of the closely allied C. (A.) bolitinos sp. nov. Rearedfromthe dung of the african buffalo, blue wildebeest and cattle in south africa. Onderstepoort J Vet Res. 1989;56:23-39.

18. Nevill EM. Biological studies on some South African Culicoides species (Diptera: Ceratopogonidae) and the morphology of their immature stages. MSC (Agric) thesis. Onderstepoort, South Africa: Pretoria University; 1967.

19. Nevill H, Venter GJ, Meiswinkel R, Nevill EM. Comparative descriptions of the pupae of five species of the Culicoides imicola complex (Diptera, Ceratopogonidae) from South Africa. Onderstepoort J Vet Res. 2007;74:97-114.

20. Zimmer JY, Haubruge E, Francis F. Review: larval ecology of Culicoides biting midges (Diptera: Ceratopogonidae). Biotechnol Agron Soc Environ. 2014;18(2):301-12 (In French). 
21. Diarra M, Fall M, Fall AG, Diop A, Seck MT, Garros C, et al. Seasonal dynamics of Culicoides (Diptera: Ceratopogonidae) biting midges, potential vectors of African horse sickness and bluetongue viruses in the Niayes area of Senegal. Parasit Vectors. 2014;7(147):1-11.

22. Diarra M, Fall M, Lancelot R, Diop A, Fall AG, Dicko A, et al. Modelling the abundances of two major Culicoides (Diptera: Ceratopogonidae) species in the Niayes Area of Senegal. PLoS One. 2015;10(6):e0131021.

23. Mayo CE, Osborne CJ, Mullens BA, Gerry AC, Gardner IA, Reisen WK, et al. Seasonal variation and impact of waste-water lagoons as larval habitat on the population dynamics of Culicoides sonorensis (Diptera:Ceratpogonidae) at two dairy farms in Northern California. PLoS One. 2014;9(2):1-9.

24. Foxi C, Delrio G. Larval habitats and seasonal abundance of Culicoides biting midges found in association with sheep in northern Sardinia, Italy. Med Vet Entomol. 2010;24:199-209.

25. Zimmer JY, Brostaux Y, Haubruge E, Francis F. Larval development sites of the main Culicoides species (Diptera: Ceratopogonidae) in northern Europe and distribution of coprophilic species larvae in Belgian pastures. Vet Parasitol. 2014;205(3-4):676-86.

26. O'Rourke MJ, Loomis EC, Smith DW. Observations on some Culicoides variipennis (Diptera, Ceratopogonidae) larval habitats in areas of bluetongue virus outbreaks in California. Mosq News. 1983;43:147-52.

27. Cannon LRG, Reye EJ. A larval habitat of the biting midges Culicoides brevitarsis Kieffer (Diptera: Ceratopogonidae). Aust J Entomol. 1966;5:7-9.

28. Yanase T, Matsumoto Y, Matsumori Y, Aizawa M, Hirata M, Kato T, et al. Molecular identification of field-collected Culicoides larvae in the southern part of Japan. J Med Entomol. 2013;50(5):1105-10.

29. Poddar TK, Ray S, Choudhury A. Ecology of larval Culicoides oxystoma (Diptera: Ceratopogonidae) in the Hooghly estuary, Sagar Island India. Ann Entomol. 1992;10(1):19-25

30. Ray S, Choudhury A. Vertical distribution of a biting midge, Culicoides oxystoma (Diptera: Ceratopogoniadae) during different seasons in the Hooghly Estuary, Sagar Island, India. Insect Sci Applic. 1988;9(3):329-33.

31. Harrup LE, Purse BV, Golding N, Mellor PS, Carpenter S. Larval development and emergence sites of farm-associated Culicoides in the United Kingdom. Med Vet Entomol. 2013;27(4):441-9.

32. Ninio C, Augot D, Dufour B, Depaquit J. Emergence of Culicoides obsoletus from indoor and outdoor breeding sites. Vet Parasitol. 2011;183(1-2):125-9.

33. Luhken R, Steinke S, Wittmann A, Kiel E. Impact of flooding on the immature stages of dung-breeding Culicoides in Northern Europe. Vet Parasitol. 2014;205(1-2):289-94.

34. Steinke S, Luhken R, Kiel E. Assessment of the abundance of Culicoides chiopterus and Culicoides dewulfi in bovine dung: a comparison of larvae extraction techniques and emergence traps. Vet Parasitol. 2014;205(1-2):255-62.

35. Braverman Y. Characteristics of Culicoides (Diptera, Ceratopogonidae) breeding places near Salisbury, Rhodesia. Ecol Entomol. 1978;3:163-70.

36. Nevill EM. Asignificant new breeding site of Culicoides pallidipennis Carter, Ingram and Macfie (Diptera: Ceratopogonidae). I S Afr Vet Med Assoc. 1968;39:61

37. Blackwell A, King FC. Vertical distribution of Culicoides impunctatus larvae. Med Vet Entomol. 1997;11:45-8.

38. Uslu U, Dik B. Vertical distribution of Culicoides larvae and pupae. Med Vet Entomol. 2006;20(3):350-2.

39. Hribar $L$. A review of methods for recovering biting midge larvae (Diptera: Ceratopogonidae) from substrate samples. J Agric Entomol. 1990;7(1):71-7.

40. Schwenkenbecher JM, Mordue AJ, Switek K, Piertney SB. Discrimination of Culicoides midge larvae using multiplex polymerase chain reaction assays based on DNA sequence variation at the mitochondrial cytochrome C oxidase I gene. J Med Entomol. 2009;46(3):610-4.

41. Bakhoum MT, Fall M, Fall AG, Bellis GA, Gottlieb Y, Labuschagne K, et al. First record of Culicoides oxystoma Kieffer and diversity of species within the Schultzei group of Culicoides Latreille (Diptera: Ceratopogonidae) biting midges in Senegal. PLoS One. 2013;8(12):e84316.

42. Fall M, Diarra M, Fall AG, Balenghien T, Seck MT, Bouyer J, et al. Culicoides (Diptera: Ceratopogonidae) midges, the vectors of African horse sickness virus - a host/vector contact study in the Niayes area of Senegal. Parasit Vectors. 2015;8(1):39.

43. Akakpo A, Wombou Toukam CM, Mankor A, Ly C. Economic impact of African horse sickness outbreak in Senegal in 2007. Bull Anim Hith Prod Afr. 2011;59:1-16.

44. Diouf ND, Etter E, Lo MM, Lo M, Akakpo AJ. Outbreaks of African horse sickness in Senegal, and methods of control of the 2007 epidemic. Vet Rec. 2012;172(6):152.
45. Steinke S, Luhken R, Balczun C, Kiel E. Emergence of Culicoides obsoletus group species from farm-associated habitats in Germany. Med Vet Entomol. 2016;30(2):174-84

46. Cornet $M$, Brunhes J. Révision des espèces de Culicoides apparentées à $C$. shultzei (Enderleini, 1908) dans la région afro-tropicale (Diptera: Ceratopogonidae). Bull Soc Entomol Fr. 1994;92(2):149-64.

47. Glick Jl. Culicoides biting midges (Diptera: Ceratopogonidae) of Kenya. J Med Entomol. 1990;27(2):85-195.

48. Boorman J. Culicoides (Diptera: Ceratopogonidae) of the Arabian peninsula with notes on their medical and veterinary importance. Fauna of Saudi Arabia. 1989:10:160-224.

49. Bakhoum MT, Fall M, Seck MT, Gardès L, Fall AG, Diop M, et al. Foraging range of arthropods with veterinary interest: new insights for Afrotropical Culicoides biting midges (Diptera: Ceratopogonidae) using the ring method. Acta Trop. 2016;157:59-67.

50. Fall M, Fall AG, Seck MT, Bouyer J, Diarra M, Balenghien T, et al. Circadian activity of Culicoides oxystoma (Diptera: Ceratopogonidae), potential vector of bluetongue and African horse sickness viruses in the Niayes area, Senegal. Parasitol Res. 2015;114(8):3151-8.

51. Fall M, Fall AG, Seck MT, Bouyer J, Diarra M, Lancelot R, et al. Host preferences and circadian rhythm of Culicoides (Diptera: Ceratopogonidae), vectors of African horse sickness and bluetongue viruses in Senegal. Acta Trop. 2015;149:239-45.

52. Paweska JT, Prinsloo S, Venter GJ. Oral susceptibility of South African Culicoides species to live-attenuated serotype-specific vaccine strains of African horse sickness virus (AHSV). Med Vet Entomol. 2003;17(4):436-47.

53. Venter GJ, Mellor PS, Paweska JT. Oral susceptibility of South African stockassociated Culicoides species to bluetongue virus. Med Vet Entomol. 2006; 20(3):329-34.

54. Venter GJ, Paweska JT, Van Dijk AA, Mellor PS, Tabachnick WJ. Vector competence of Culicoides bolitinos and C. imicola (Diptera: (eratopogonidae) for South African bluetongue virus serotypes 1, 3 and 4 Med Vet Entomol. 1998;12:378-85.

55. Labuschagne K. The Culicoides Latreille (Diptera: Ceratopogonidae) species of South Africa. South Africa: University of Pretoria; 2015.

56. Oem JK, Chung JY, Kwon MS, Kim TK, Lee TU, Bae YC. Abundance of biting midge species (Diptera: Ceratopogonidae, Culicoides spp.) on cattle farms in Korea. J Vet Sci. 2013;14(1):91-4.

57. Yanase T, Kato T, Kubo T, Yoshida K, Ohashi S, Yamakawa M, et al. Isolation of bovine arboviruses from Culicoides biting midges (Diptera: Ceratopogonidae) in southern Japan: 1985-2002. J Med Entomol. 2005;42:63-7.

58. El Sinnary K, Hussein HS. Culicoides kingi, Austen: a vector of Onchocerca gutturosa (Neumann, 1910) in the Sudan. Ann Trop Med Parasitol. 1980; 74(6):655-6.

59. Auriault M. Contribution à l'étude biologique et écologique de Culicoides grahamii (Austen), 1909, (Diptera, Ceratopogonidae). Cah ORSTOM, sér Ent méd Parasitol. 1978;XVI(2):87-93.

60. Conraths FJ, Eschbaumer M, Freuling C, Gethmann J, Hoffmann B, Kramer $\mathrm{M}$, et al. Bluetongue disease: an analysis of the epidemic in Germany 2006-2009. In: Mehlhorn H, editor. Arthropods as vectors of emerging diseases. Berlin: Springer Berlin Heidelberg; 2012. p. 103-35.

61. Venail R, Mathieu B, Setier-Rio ML, Borba C, Alexandre M, et al. Laboratory and field-based tests of deltamethrin insecticides against adult Culicoides biting midges. J Med Entomol. 2011;48(2):351-7.

62. Mullens BA, Gerry AC, Sarto V, Monteys I, Pinna M, Gonzalez A. Field studies on Culicoides (Dipetera: Ceratopogonidae) activity and response to deltamethrin applications to sheep in northeastern Spain. J Med Entomol. 2010;47:106-10. 